\title{
THE LEGAL REGULATION \\ OF RENTAL CONTRACTS ON THE LAND RENTAL MARKET IN SLOVAKIA
}

\author{
PRÁVNA ÚPRAVA \\ NÁJOMNÝCH ZMLÚV NA TRHU \\ S PRENAJÍMANÍM PÔDY NA SLOVENSKU
}

\author{
Ivan TAKÁČ * Jarmila LAZÍKOVÁ**
}

\section{Introduction}

Since accession of ten new member states ${ }^{(1)}$, (NMS) to the EU in 2004 and two countries in 2007, NMS farmers are eligible to payments within the framework of the EU Common Agricultural Policy (CAP) (Bandlerová, Schwarczová, Schwarcz, 2012 and Lazíková, Dimitrova, 2008). In the NMS the issue

(1) The new EU member states are the European states which have accessed to the EU after May 1, 2004 and January 1, 2007. There are Slovakia, Slovenia, Czech Republic, Poland, Hungary, Malta, Cyprus, Latvia, Lithuania, Estonia and Rumania and Bulgaria.

\section{Abstract (EN)}

Rented land accounted for $53 \%$ of the total agricultural area at EU-27 level in 2009. Rented land as a proportion of total utilized agricultural area in Slovakia (UAA) is one of the highest (FADN, 2009). That is why land rent plays a very important role. Therefore, the Slovak law maker approved special legal regulation to stabilize the long-term rent of agricultural land. The paper analyses how these legal norms affect the behaviour of the land tenants doing their business activities in the agriculture. Within the paper, the development of the market farmland prices and farmland rental payments development with the administrative land prices and rental payments stipulated by the Slovak national law is analysed. Based on the research results we found out that prices of arable land have statistically significantly increased. In spite of these facts the market prices are still lower than their administrative prices ${ }^{(1)}$ especially in the case of farmland of the highest quality. According to the results the rent payment for one hectare of land is not influenced by the minimum rent payment stipulated by law. Contrary, minimum rental period stipulated by law, legal forms of agricultural enterprises and quality of land have significant impact on the rental payments. The larger acreage of land of one agricultural businessman press down the land rent payments. The legal forms of enterprises as well as the land rent period belong to the dominant factors which influence the land rent payment.

(1) Administrative price is a price of farmland stipulated by the law.

\section{Keywords (EN)}

agricultural land, land rent, legal regulation, rent payment, rent period, revenues from the agricultural business is even more sensitive for farmland prices, rental payments and share of rented farmland. In the NMS, on average 52 per cent of agricultural land is rented, but there is wide variation in the share of rented land among countries and types of farms. The share of rented farmland varies between 28 per cent in Poland to 96 per cent in Slovakia (Ciaian and Kancs, 2009). The share of rented farmland in Slovakia is one of the highest in the European Union. Slovakia is a small European country with farmland covering about $19300 \mathrm{~km}^{2}$ which represents 39\% of the total area (Green report, 2009). Although the rental market is more developed in Slovakia, the country's accession to the European Union has stimu-

\section{Abstrakt (SK)}

Podiel prenajatej pôdy v EÚ predstavoval v roku 2009, 53\% z celkovej výmery pol'nohospodárskej pôdy. Na Slovensku je prenájom pôdy, ako podiel z celkovej využivanej polnnohospodárskej pôdy jeden z najväčších (FADN, 2009). Prenájom pozemkov teda zohráva velmi dôležitú úlohu, a preto bol slovenskými zákonodarcami schválený osobitný právny predpis, ktorý by stabilizoval dlhodobý prenájom polnohospodárskej pôdy. Príspevok sa zaoberá tým, ako právna úprava ovplyvňuje správanie sa nájomcov pozemkov z pohladu ich podnikatel'ských aktivit v polnohospodárstve. $V$ príspevku je analyzovaný vývoj trhových cien polnohospodárskej pôdy a nájomného, v porovnaní s úradnými cenami pôdy a nájomným, ktoré sú upravené slovenskou legislatívou. Z dosiahnutých výsledkov sme zistili, že trhová cena ornej pôdy sa štatisticky významne zvýšila, napriek tomu sú trhové ceny stále nižšie ako úradné ceny, najmä v prípade polnohospodárskej pôdy najvyššej kvality. Podla dosiahnutých výsledkov nie je nájomné na jeden hektár pôdy ovplyvnené minimálnou zákonnou výškou nájomného. Naopak minimálna doba nájmu stanovená zákonom, právna forma polnohospodárskych podnikov a kvalita pôdy majú významný vplyv na nájomné. Čím je väčšia výmera pôdy jedného polnohospodárskeho subjektu, tým výraznejšie je stlačené nájomné za pôdu. Právna forma podnikania, ako aj doba nájmu predstavujú dominantné faktory, ktoré majú vplyv na výšku nájomného.

\section{Klúčové slová (SK)}

pol'nohospodárska pôda, nájom k pôde, právna úprava, nájomné, dláka nájmu, prijmy z pol'nohospodárskeho podnikania

\footnotetext{
* Slovak University of Agriculture, Nitra
}

** Slovak University of Agriculture, Nitra 
lated land sales. The areas of sold farmland were decreasing during 2001 - 2003 but after 2004 this trend has reserved and the area of sold farmland increased by 100 per cent in 2005 relative to 2003 (Takáč, 2009). This has influenced also the farmland prices, which increased by 81 per cent in 2005 - 2009 (after the EU accession) relative to 1999 - 2004 (before the EU accession) (Lazíková, Takáč, 2010).

The development of land market in Slovakia is influenced by the EU law (CAP) and by the Slovak national law as well.

\section{Aim, material and methods}

The objective of this paper is to analyse the development of farmland prices in Slovakia and to identify their determinants.

The remainder of the paper is organised as follows. In first section, we analyse a relation between market farmland prices and administrative land prices. In section two, we analyse the influence of the legal regulation of rental contracts on the land rental market. On third part we relation between land quality and rental payments. The last section summarises and draws conclusions.

This paper uses the results of VEGA project no. 1/0876/11 and Jean Monnet Programme "EU Business Law" no. 175785LLP-1-2010-1-SK-AJM-MO.

\section{Results and Discussion}

\section{Farmland Prices in Slovakia after the EU Accession}

We compared the market farmland prices (2005-2010) with the administrative land prices stipulated by the Slovak national law. There are two legal acts stipulated the types of administrative prices of agricultural land depending up the purpose which should be used.

The first one is the legal act No. 582/2004 Coll. on local property taxes, that regulates the property taxes related to the land and other real estates. The second one is the legal act No. 38/2005 Coll. on the land value for the purpose of land arrangement. This legal act stipulated the land value depending up the land quality. We found by the comparison that market farmland prices are significantly lower relative to their administrative counterparts (Figure 1).

Administrative farmland prices are depicted on the horizontal axis while on the vertical axis we report the market prices. The solid line depicts a situation when the administrative and market farmland prices are equals. The individual single points are the market transaction which includes the market land prices. All these points are under the solid line which means that the administrative prices are higher than market ones.

The second legal act No. 38/2005 Coll. on the land value stipulates the administrative prices for the purpose of land arrangement depending up the land quality. These administrative prices are three times lower than the administrative prices stipulated according to the legal act No. 582/2004 Coll. but neither the legal act No. 582/2004 Coll. nor the explanatory report to this act explain the reason of legislator to stipulated the prices of the same land three times higher according to the first legal act in comparison to the second one.

Administrative farmland prices are depicted on the horizontal axis while on the vertical axis we report the market prices. The higher land quality corresponds with the higher administrative farmland price. The solid line depicts a situation when the administrative and market farmland prices are equals. The individual single points are the market transactions which include the market land prices. In this case, there were some transactions for the higher prices than administrative ones. It is interesting that the farmland of lower quality was sold more expensive relative to the administrative prices than the higher quality farmland.

\section{The farmland rental payments development}

The farmland rental contracts are usually concluded for a period 5 - 10 years. It follows that the significant changes will be possible to measure after the termination of these contracts, because the rental payments are often negotiated as a fixed sum during whole period of land tenure. Therefore, this section is intent on the legal changes related to the land tenure and adopted just after the accession of Slovakia to the EU. In 2004, the new legal act No. 504/2003 Coll. on agricultural land tenure, agricultural enterprise lease and forestland tenure as amended by the later statutes (hereinafter referred to as the Act on land tenure) was adopted. This one regulates the land tenure in two different situations:

- land tenure for agricultural purposes (the legislator presumes short-term, fix-term and occasional tenure of smaller and integrated land plots);

- land tenure for agricultural business in the course of managing an agricultural enterprise, where the land is used for agricultural production; there are high-cost investments into maintenance, regeneration and increasing of land fertility, into the high-power technology for plant production and into transport, infrastructure and buildings (Lazíková, Bandlerová, 2008).

In the case of entrepreneur land tenure, that means the land tenure for agricultural purposes in course of enterprise, the law requires an agreement on the rent or agreement on the means of its determination. The minimum amount is $1 \%$ of the land value determined according to the legal act No. $38 / 2005$ Coll. on the determination of the value of the land and the plants growing on it for the purposes of land adjustments as amended by later regulations (Lazíková, Bandlerová, 2009). According to the empirical findings, we can state that the market rental payments are higher than the minimal rental price required by the law. It is documented in Figure 3 and 4 . The minimal rental payments required by the law are depicted on the horizontal axis while on the vertical axis we report the market rental payments. The solid line depicts a situation, where the minimal rental payments required by law and the market rental payments are equal. The most of monitored market rental payments are upon the solid lines. That mean they are higher than the minimal rental payments required by the law. It follows that the legal 


\section{Agrárne ročník III vydanie $1 / 2013$ právo EU'}

Figure 1: Relation between market farmland prices and administrative land prices according to the 582/2004 Coll. $[30,126 \mathrm{SKK} / €]$

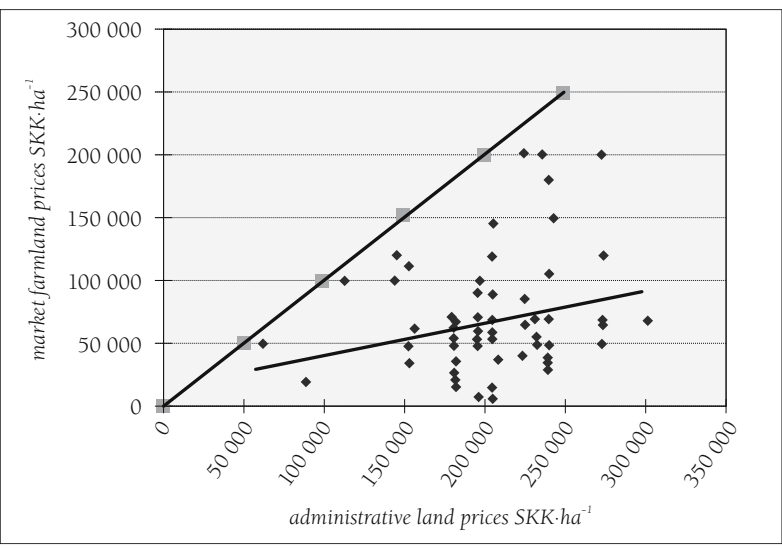

Figure 2: Relation between market farmland prices and administrative land prices according to the 38/2005 Coll $[30,126 \mathrm{SKK} / €]$

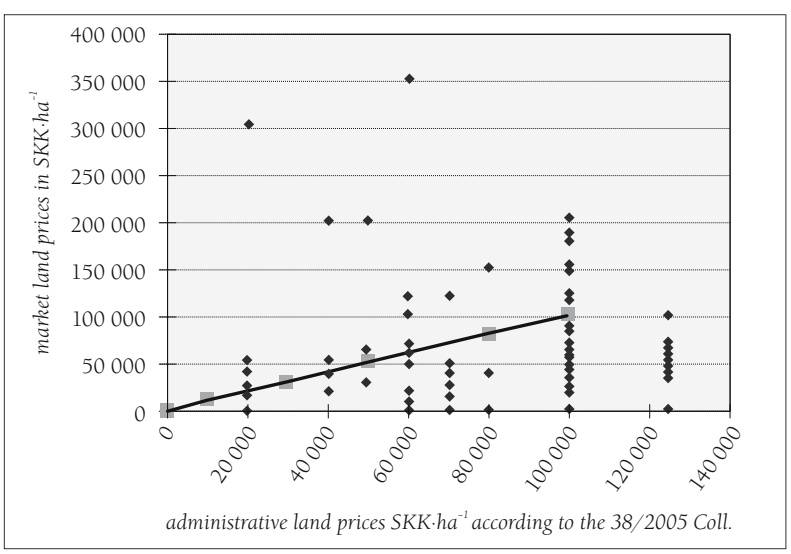

Figure 3: Land rental payments after 2004 [30,126 SKK / €]

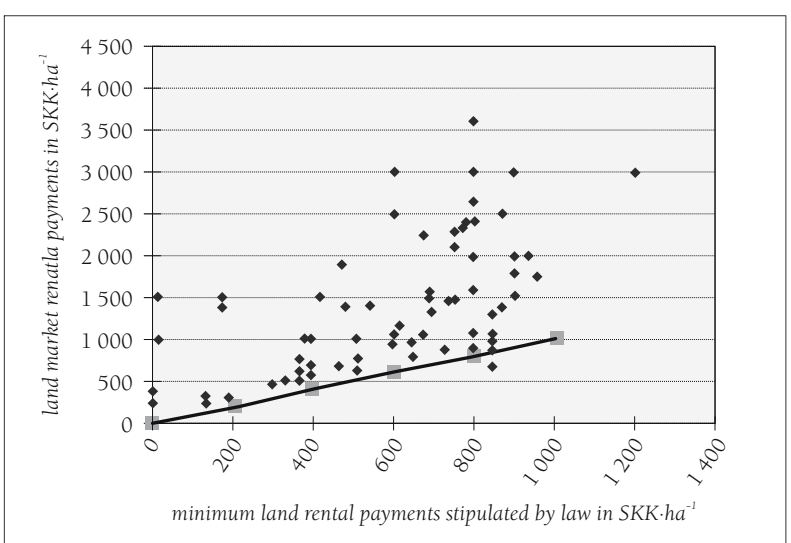

regulations is obsolete. For all that we tried to find if the legal statement about the minimal rental price had its sense at the time of its adoption.

But the Figure 4 proves that the market rental payments were higher than the minimal ones before the legal act adoption. The legal statement about the minimal rental price is obsolete from the date of its adoption.

The figure 3 and 4 prove the uselessness of the legal rule about the minimal rental price but point out another inter-

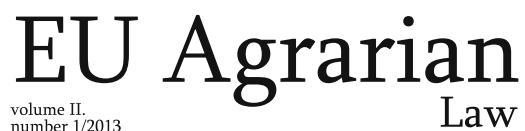

Figure 4: Land rental payments before 2004 [30,126 SKK / €]

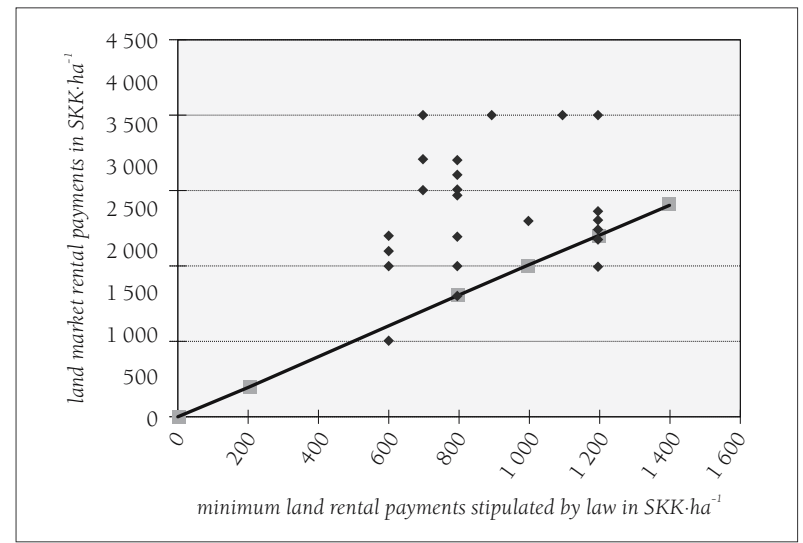

Figure 5: Relation between land quality and rental payments

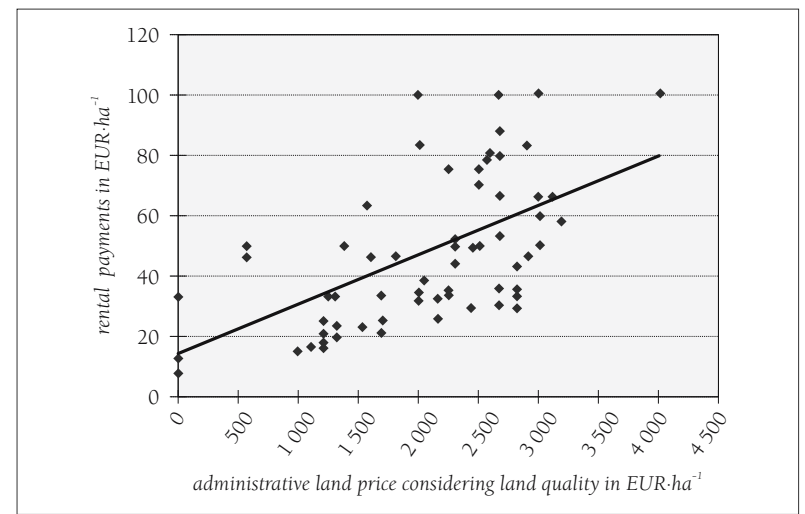

Figure 6: Problems on the land market from the view of farmers

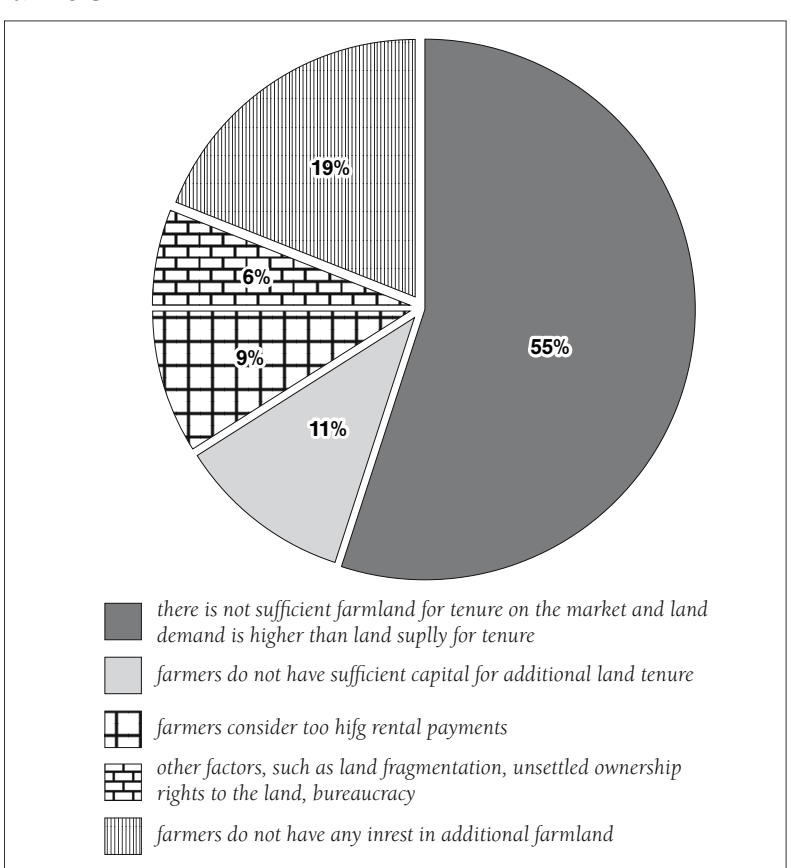

esting consequence. We have already stated that the legal act No. 38/2005 Coll. stipulated the land value depending up the land quality. The minimal rental payments required by this law depicted on the horizontal axis represents the 
Table 1: ANOVA results of relation between the rental payments and legal form of enterprises

\begin{tabular}{|c|c|c|c|c|c|c|}
\hline \multicolumn{7}{|c|}{ Anova: Single Factor } \\
\hline \multicolumn{7}{|c|}{ Factor } \\
\hline Groups & Count & Sum & Average & Variance & & \\
\hline Joint stock companies & 10 & $8,040.629$ & 804.0629 & $244,429.2$ & & \\
\hline Limited liability companies & 29 & $5,4470.93$ & $1,878.308$ & $520,404.1$ & & \\
\hline Cooperatives & 49 & $5,8478.92$ & $1,193.447$ & $637,416.4$ & & \\
\hline Individual Farmers & 11 & $2,0673.25$ & $1,879.387$ & $966,898.6$ & & \\
\hline \multicolumn{7}{|c|}{ ANOVA } \\
\hline Source of Variation & SS & df & MS & $\mathrm{F}$ & P-Value & F crit \\
\hline Between Groups & $14,709,632$ & 3 & $4,903,211$ & 8.166839 & $6.81 \times 10^{-05}$ & 2.700409 \\
\hline Within Groups & $57,036,147$ & 95 & $600,380.5$ & & & \\
\hline Total & $71,745,780$ & 98 & & & & \\
\hline
\end{tabular}

Table 2: ANOVA results of relation between the rental payments and period of land tenure

\begin{tabular}{|c|c|c|c|c|c|c|}
\hline \multicolumn{7}{|c|}{ Anova: Single Factor } \\
\hline \multicolumn{7}{|c|}{ Factor } \\
\hline Groups & Count & Sum & Average & Variance & & \\
\hline Tenure of 5 years & 13 & $28,707.45$ & $2,208.265$ & $417,014.6$ & & \\
\hline Tenure up to 10 years & 48 & $68,522.81$ & $1,427.558$ & $795,977.5$ & & \\
\hline Tenure up to 15 years & 14 & $18,818.93$ & $1,344.21$ & $200,224.9$ & & \\
\hline Tenure for an indefinite period of time & 21 & $28,347.32$ & $1,349.873$ & $513,704.0$ & & \\
\hline \multicolumn{7}{|l|}{ ANOVA } \\
\hline Source of Variation & SS & df & MS & $\mathrm{F}$ & P-Value & F crit \\
\hline Between Groups & $7,584,659$ & 3 & $2,528,220$ & 4.206679 & 0.007771 & 2.703594 \\
\hline Within Groups & $55,292,121$ & 92 & $601,001.3$ & & & \\
\hline Total & $62,876,780$ & 95 & & & & \\
\hline
\end{tabular}

land quality; it means that the higher minimal rental payments represents the higher land quality. According to the graphs analysis we can state, that the market rental payments depend on the land quality. The minimal rental payments (horizontal axis) are derived from the administrative value of land stipulated according to the land quality. The relation is documented in Figure 5.

However, the land quality is not only one factor influencing the market rental payments. The legal form of land user (tenant) was a second factor influencing the land rental payments. The individual farmers pay higher rental payments than agricultural cooperatives. There were statistical significant differences in the land rental payments depending on the legal form of agricultural enterprises. The table 2 presents the results.

According to the ANOVA test the highest rental price is paid by individual farmers and limited liability companies. The lowest rental payments are paid by the joint stock companies and cooperatives. This situation is caused by the fact that joint stock companies and cooperatives cultivate the most of farmland. According to the Green report (2006) an average acreage of a joint stock company is app. 1285 ha and a cooperative app. 1367 h; a limited liability company cultivates in average only 652 ha and an individual farmer only 43 ha. It follows logically, that the large agricultural enterprises do not interest in receiving the additional unit of farmland as much as the agricultural enterprises cultivating the small acreage of land. The willingness of smaller farmers to supply the higher rental payments consists in effort to receive additional hectares of farmland for more effective farming. Furthermore it is typically situation that there is lower competition in the regions where the land is cultivated by the large agricultural enterprises. It causes that they are not motivated to supply higher rental payments. On the contrary, the regions with the more density of agricultural enterprises cultivating smaller acreage of farmland are the higher competition to receive additional land for tenure. That is reason for higher rental payments of land tenure. According to our survey we found that not only the smaller farmer but also the large agricultural companies have an interest in additional farmland tenure. The demand of farmland tenure is higher than the supply. 55 per cent of respondents considered the first problem on the farmland market are insufficient of farmland for tenure and the unwillingness of land owners to leave it for tenure. There were no differences among the respondents' answers in relations to the region or legal form of agricultural enterprises.

According to these problems we could expect the increase of land rental payments; however, it is not simple in the praxis because of legal regulation. According to the Act on land tenure a contract on land tenure for agricultural business has 
to be concluded for a period of at least five years. This legal regulation is in favour of land tenants. They are not motivated to pay higher rental payments and the legal regulation provides them the legal security of land use for a minimum period of time stipulated by law. It is a reaction of the law making bodies on the lack of land owner's interest in their own land cultivation when receiving the land after the transformation process. For all that we consider hypothesis: the protection of land tenants providing by the legislator is compensated in favour of land owner by the way that for a longer period of time is given a higher rental price for a hectare of land per year.

According to the results of Anova test we have to state the highest rental payments are provided in the case of the shortest period of land tenure. The period of five years is preferred by limited liability companies and individual farmers paying the highest rental payments according to the previous analysis. The agricultural cooperatives paying one of the lowest rental payments prefer the period of land tenure at least 10 years or an indefinite period. We expect that the cancelation of the legal regulation related to the minimum period of land tenure will cause that the agricultural companies, mainly individual farmers will prefer a shorter period of land tenure than is it stipulated by law. But in this case there is a question what is the reason of a minimum period of land tenure stipulated by law.

\section{Conclusion}

In Slovakia the vast majority of agricultural land is rented and cultivated by the tenants, not by the owner. The Slovak law maker adopts a special legal regulation with the aim to stabilise the land rent relations, to protect the interests of the agricultural land tenants and to protect the soil as the natural resource. There is a question how these legal norms affects the behaviour of the land tenants doing their business activities in the agriculture.

According to our findings we can state that (1) market farmland prices are significantly lower relative to their administrative counterparts. It is interesting that the farmland of lower quality was sold more expensive relative to the administrative prices than the higher quality farmland. According to the empirical findings, we can state that (2) the market rental payments are higher than the minimal rental price required by the law, that means the legal regulations is obsolete. We find that the legal statement about the minimal rental price is obsolete from the date of its adoption. According to findings we can state, that (3) the market rental payments depend on the land quality, and minimal rental payments are derived from the administrative value of land stipulated according to the land quality. (4) The legal form of land user was a second factor influencing the land rental payments. There were statistical significant differences in the land rental payments depending on the legal form of agricultural enterprises. The individual farmers pay higher rental payments than agricultural cooperatives.

According to the Act on land tenure a contract on land tenure for agricultural business has to be concluded for a period of at least five years. This legal regulation is in favour of land tenants. They are not motivated to pay higher rental payments and the legal regulation provides them the legal security of land use for a minimum period of time stipulated by law.The present legal regulation of the land rent relations does limited the business plans of the young farmers and protect sufficiently old farmers (e.g. Cooperatives).We recommend changing the national legislation to be less restrictive in the terms of land contracts and more helpful for land market transparency by creation of information system on land market transaction.

\section{References}

[1] Bandlerová, A. et al. (2/2012) Acquisition of agricultural land by foreigners - the case of Slovakia. Nitra: EU Agrarian law. p. $32-38$. ISSN 1338-6891.

[2] Buday, Š. et al. (2007) Monitoring of the agricultural land market, land rent and rent payment in the selected regions of the Slovak republic and its multifactorial analysis for the year 2005. Bratislava: Research institute of the agricultural and food economics. ISBN 978-80-8058-463-4.

[3] Ciaian, P - Kancs, A. 2009. The capitalisation of Area Payments into Farmland Rents: Theory and Evidence from the New EU Member States. Brusel: EERI Research Paper Series No. 04/2009 ISSN 2031-4892.

[4] Lazíková, J. - Bandlerová, A. 2008. AgriculturalLandLease in Slovakia. In: IlDirittodell'Agricoltura, Rivistaquadrimestraledirettadafelice Casucci, Napoli: EdizioniScientificheItaliene, 1/2008, p. 65 - 82. ISSN 1720 - 4445.

[5] Lazíková, J. - Bandlerová, A. 2009. Právne aspekty nájmu polnohospodárskej pôdy v SR. In: Právník, Praha: Ústav státu a práva $\mathrm{AV}$ ČR, v.v.i., č. 5 , roč. 148 , 2009. s. $500-523$ ISSN $0231-6625$

[6] Lazíková, J. - Dimitrova, V. 2008. Landownership in Slovakia and Bulgaria. Enterpreneurship on agriculturalland in EÚ-27. Nitra, Slovakia. ISBN 978-80-552-0041-5.

[7] Lazíková, J - Takáč, I. 2010. Právne a ekonomické aspekty nájmu polnohospodárskej pôdy. 1. vydanie. Nitra: SPU, 2010, 100 s. ISBN 978-80-552-0447-5.

[8] Slovak LandFund. Annual report. 2008 [on-line]. [cit. 2012.01.12] <http://www.pozfond.sk/_documents/ZakladneInformacie/Vyrocna_Sprava_2008.pdf>.

[9] Ministry of agriculture of the Slovak republic (2009). Report on agriculture and food industry in the Slovak republic 2009. Bratislava.

[10] Law no. 504/2003 on agricultural land rent, agricultural enterprise rent and forestland rent [online] 25.05.2012 <http: // jaspi.justice.gov.sk>.

[11] EU FarmEconomicsOverview - FADN, 2009 p.40-41 [on-line]. [cit. 2013.10.1] <http://ec.europa.eu/agriculture/rica/ pdf/report_2009.pdf>.

\section{Contact address/ Kontaktná adresa}

Ing. Ivan Takáč, PhD., Department of European Policies,

Slovak Agricultural University in Nitra, Tr. A. Hlinku 2, 94976 Nitra, Slovakia

e-mail: Ivan.Takac@gmail.com

JUDr. Ing. Jarmila Lazíková, PhD., Department of Law, Slovak Agricultural University in Nitra, Tr. A. Hlinku 2, 94976 Nitra, Slovakia,

e-mail: Jarmila.Lazikova@uniag.sk 